\author{
Pawee Hut \\ UNIWERSYTET WARSZAWSKI \\ E-MAIL:PAWEL.HUT@UW.EDU.PL
}

\title{
ZAGRANICZNI RODACY I POGRANICZA W EUROPIE ŚRODKOWO-WSCHODNIEJ PO 1989/1990 ROKU
}

\section{Wstęp}

Celem niniejszego artykułu jest próba przedstawienia zmian, które nastąpiły po przełomie 1989/1990 roku na obszarach określanych jako pogranicza. Ten sięgający czasów współczesnych okres ćwierćwiecza charakteryzował się zmienną dynamiką rozmaitych procesów w sferach: politycznej, społecznej, kulturowej i gospodarczej. Ich specyfika na pograniczach przejawiała się ze szczególną swoistością: od brutalnej eksterminacji po spory rozstrzygane $\mathrm{w}$ sposób uwzględniający cele przeciwnych stron, a nastąpiła wskutek zniknięcia ideologicznego przymusu wynikającego z totalitarnej natury systemu politycznego. Tłumione przez dziesięciolecia napięcia na tle etnicznym, w sytuacji narzucenia powojennego przebiegu granic, objawiły się w postaci wzrostu aspiracji niepodległościowych, separatyzmów i sporów międzypaństwowych o różnej intensywności.

Z perspektywy polityki społecznej jest to istotny obszar zainteresowań badawczych, ponieważ bezpośrednio łączy się z kategorią kwestii społecznej - stanu uniemożliwiającego zaspokojenie podstawowych potrzeb ludzkich. Występujące na pograniczach Europy Środkowo-Wschodniej problemy społeczne miały dotkliwy wpływ na funkcjonowanie całych zbiorowości. Warto też podkreślić, że badania pogranicza wpisują się w tradycję badawczą polityki społecznej. Jej początków można upatrywać w pracach Ludwika Krzywickiego i Marii Niemyskiej-Hessen [Niemyska 1936; Niemyska-Hessen 1939]. Punktem wyjścia rozważań badaczy Instytutu Gospodarstwa Społecznego było przekonanie o szczególnym ryzyku niezaspokojenia potrzeb szerokich grup ludności na pograniczu; współcześnie ich praca jest kontynuowana w środowisku polityków społecznych. 


\section{Zagraniczni rodacy i zagraniczna ojczyzna}

Przede wszystkim wyjaśnienia wymaga rozumienie przez autorów artykułu kluczowych pojęć. Do nich zalicza się występujące w literaturze przedmiotu pojęcie „rodacy z zagranicy” lub „zagraniczni rodacy” [Brubaker 1998: 7]. Są to osoby uznające swoją więź z narodem żyjącym w innym państwie, o ile dana grupa tworzy takie państwo (w Europie Środkowo-Wschodniej wyjątkami są na przykład Serbołużyczanie, Łemkowie, Romowie). Warto też określić, jaka przesłanka decyduje o więzi - czy jest to wyłącznie związek z grupą etniczną czy także związek z określonym terytorium. Autorzy skłaniają się do uznania, że istotniejszy jest związek z grupą, ale jednocześnie w uzasadnionych przypadkach - szczególnie na obszarach zasiedlanych przez ludność o mniej utrwalonej tożsamości etnicznej kryterium terytorialne również posiada znaczenie, tym bardziej, gdy chodzi o nowe kraje utworzone przez grupy nieposiadające tradycji państwowej. Warto też rozstrzygnąć, czy posługując się określeniem zagraniczni rodacy ma się na myśli autochtoniczną ludność, która wskutek zmian przebiegu linii granicznych znalazła się w innym państwie czy też kategoria ta obejmuje również migrantów, którzy z różnych przyczyn, mieszkają poza „historyczną ojczyzną”. Autorzy skłaniają się do jak najszerszego rozumienia pojęcia zagranicznych rodaków, ponieważ pozwala to na uwzględnienie środkowo-wschodniej specyfiki procesów, w tym związanych na przykład z przymusowymi deportacjami całych grup ludności, których efektem jest pozostawanie licznych grup o utrwalonej tożsamości nie tylko poza ojczystym państwem, ale nawet poza dawnym terytorium zamieszkania (na przykład deportowani do Kazachskiej SRS). Natomiast dla rozróżnienia czasowych migrantów poszukujących na przykład zatrudnienia poza krajem obywatelstwa, należy podkreślić trwałość pobytu zagranicznych rodaków w innym państwie - często jest to kolejne pokolenie przedstawicieli danej grupy etnicznej, w wyjątkowych przypadkach nawet posiadające rodzącą się świadomość odrębności od grupy z "historycznej” ojczyzny. Wreszcie, rozstrzygnięcia wymaga zagadnienie, czy zagranicznym rodakiem jest osoba, która siebie za taką uważa, czy też jako kryterium należy uznać postrzeganie przez inne osoby? Jest to zagadnienie o tyle istotne, że w pewnych przypadkach presja zewnętrzna - na przkład przez kwestionowanie lojalności wobec państwa, może skutkować zmianą świadomości etnicznej jednostek i grup. Autorzy proponują przyjęcie jako istotniejszego kryterium autoidentyfikacji, uznając 
że każda osoba ma niezbywalne prawo do samookreślenia, nawet jeśli w pewnych okresach wiąże się ono $z$ koniunkturalizmem.

Kolejnym z pojęć jest „zagraniczna ojczyzna”. Przez R. Brubakera zdefiniowana została jako państwo, którego elity określają mieszkańców innego państwa, jako członków swego narodu i uznają tę więź za przesłankę do wzięcia za nich odpowiedzialności [Brubaker 1998]. Istotne jest podkreślenie, że po 1989/1990 roku dostrzegalna jest gotowość realizowania rozmaitych form protekcji wobec obywateli innych państw przez zagraniczne ojczyzny i przede wszystkim zagraniczni rodacy takiego wsparcia oczekują. Podobnie jak w ich przypadku, podczas próby definiowania pojawia się pytanie czy zagraniczna ojczyzna to państwo zorganizowane przez grupę etniczną, do związków z którą poczuwają się przedstawiciele narodu żyjący poza jego granicami czy też zagraniczna ojczyzna to państwo obejmujące obszar, z którego wywodzą się zagraniczni rodacy? Odpowiedź na tak sformułowane pytanie, zdaniem autorów powinna uwzględniać kontekst pobytu za granicą. W przypadku grup mniejszościowych trwale żyjących na pograniczu międzypaństwowym jako zagraniczną ojczyznę należy uznać państwo zamieszkane przez grupę etniczną odczuwającą więź z częścią żyjącą za granicą. Natomiast w przypadku osób przebywających trwale poza pograniczem wydaje się bardziej uzasadnione uznanie jako priorytetowego formalnego związku z państwem obywatelstwa i regionem, z którego się wywodzą. Wówczas dominującym kryterium staje się etniczność, przy mniej lub bardziej ambiwalentnym stosunku do zagranicznej ojczyzny (na przykład Ukraińcy w Kanadzie, Polacy z Wileńszczyzny w Wielkiej Brytanii). Interesującym przykładem do rozważań o zagranicznej ojczyźnie może być przykład istniejącej do 1990 roku Niemieckiej Republiki Demokratycznej, która wraz z Niemiecką Republiką Federalną i Republiką Austrii podejmowała działania na rzecz etnicznych Niemców, żyjących w państwach bloku wschodniego - przyjmując $\mathrm{w}$ różnych akcjach przesiedleńczych $\mathrm{w}$ latach pięćdziesiątych osoby opuszczające PRL [Stola 2010: 75, 104]. Wymienione państwa $\mathrm{w}$ różny sposób poczuwające się do udzielania wsparcia rodakom żyjącym za granicą mogły być przez nich uznawane za zagraniczną ojczyznę, przy czym od lat siedemdziesiątych w środowiskach niemieckich w państwach bloku wschodniego było oczywiste, że realne wsparcie można uzyskać dzięki pomocy władz Republiki Federalnej Niemiec.

Na potrzeby dalszych rozważań niezbędne jest także określenie czym jest pogranicze. Autorzy proponują przyjąć definicję J. Chlebowczyka, który 
pogranicze językowo-etniczne rozumiał jako terytorium, na którym występują przynajmniej dwie grupy etniczne, a dalszą typologię pogranicza opierał na kryterium podobieństwa językowego. Na pograniczach stykowych (grupy o wyraźnej odrębności językowej) lub przejściowych (grupy pokrewne językowo) występują relacje obejmujące zarówno napięcia, konflikty, antagonizmy, a nawet walkę, jak też koegzystencję i współpracę [Klatta 2003: 15]. Także rozumienie pogranicza kulturowego zaproponowane przez S. Ossowskiego będzie istotne dla opisu sytuacji na pograniczach w Europie Środkowo-Wschodniej po 1989/1990 roku [Ossowski 1967: 280].

\section{Modele relacji zagranicznych rodaków i zagranicznych ojczyzn}

Kształtowanie się i utrzymywanie łączności pomiędzy skupiskami osób należących do wspólnej grupy etnicznej z jednej strony budzi wątpliwości formalne i etyczne z zakresu stosunków międzynarodowych (najczęściej podnoszona jest kwestia lojalności wobec państwa obywatelstwa i prawo do oddziaływania na obywateli innego państwa), zaś z drugiej strony istnieją liczne przykłady na dynamiczny rozwój zakresu działań podejmowanych przez zagraniczne ojczyzny na rzecz rodaków mieszkających w innych państwach (na przykład Węgry, Polska, Federacja Rosyjska).

Modelowe ujęcie tych relacji zaproponował R. Brubaker oceniając, że w tych relacjach istotną rolę odgrywają trzy zasadnicze podmioty: zagraniczna ojczyzna, narodowo zorientowane państwo (obywatelstwa) i mniejszość narodowa [Brubaker 1998: 74]. Jest to trafna charakterystyka układu relacji, niemniej jednak w ocenie autorów ma ona bardzo szeroki i ogólny wymiar, ponieważ przez dwie dekady (od 1996 roku) podtrzymywanie więzi pomiędzy wymienionymi podmiotami poddane zostało przekształceniom i wymaga doprecyzowania.

Przede wszystkim ten rodzaj relacji wymaga rozpatrywania w ujęciu: państwo pobytu (z uwzględnieniem zróżnicowanych państw i tytułów do przebywania na ich terytorium: obywatelstwo, zezwolenie na pobyt, status uchodźcy i inne formy ochrony międzynarodowej, pobyt nielegalny) i zagraniczna ojczyzna (niezależnie od podmiotów realizujących zadania z zakresu utrzymywania relacji z mniejszością). Dodatkowo w relacji tej znaczącą rolę odgrywają podmioty międzynarodowe, na przykład instytucje UE, które posiadają kompetencje w zakresie angażowania się w sprawy mniejszości narodowych. 
W państwie pobytu rozmaite działania na rzecz danej mniejszości narodowej realizowane są przez organizacje społeczne dedykowane zarówno ogólnym celom (na przykład przeciwdziałaniu ubóstwu, upowszechnianiu oświaty, szerzeniu kultury fizycznej), jak też przez szersze związki skupiające poszczególne mniejszości narodowe lub organizacje wybranej mniejszości narodowej. Z perspektywy instytucji danego państwa - poza realizującymi ogólne zadania ustawowe, mogą być to też zinstytucjonalizowane gremia zajmujące się wyłącznie sprawami mniejszości narodowych. Przykładem może być też - jak w przypadku Polski - gwarantowanie uprzywilejowanej pozycji mniejszości w wyborach parlamentarnych i ich reprezentacja w ogólnopaństwowych ugrupowaniach politycznych. W zagranicznej ojczyźnie występuje bardzo zbliżona struktura podmiotów, w której poza oczywistymi różnicami może istnieć dodatkowa reprezentacja zagranicznych rodaków.

Przedstawiony układ relacji uwzględnia też rolę pełnioną na pograniczach przez podmioty gospodarcze (narodowe przedsiębiorstwa lub spółki skarbu państwa) mające swe centrale w zagranicznych ojczyznach. Ich ekonomiczne oddziaływanie w oczywisty sposób kształtuje postrzeganie państwa, z którego się wywodzą. To zaś pozwala na dowartościowanie grupy etnicznej, nawet jeśli kierownictwo firmy świadomie dystansuje się od spraw etnicznych na pograniczu (na przykład polskie firmy na Wileńszczyźnie).

W wielu przypadkach instytucją posiadającą ogromne znaczenie na pograniczu są Kościoły. Język liturgii, pielęgnowanie tradycji i funkcjonowanie całego środowiska stwarza możliwość integracji w grupie mniejszościowej. W opracowanym przez autorów układzie relacji nie został on jednak uwzględniony, ponieważ na pograniczach w Europie Środkowo-Wschodniej można znaleźć liczne przykłady marginalnej roli Kościołów i wyznań (na przykład pogranicze czesko-słowackie, słowacko-polskie, słoweńsko-chorwackie i inne) lub kontestowanej przez dużą część wiernych postawy duchownych zmieniających tradycyjne zaangażowanie danego Kościoła w realizację celów stawianych sobie do osiągnięcia przez wybraną mniejszość narodową (na przykład Kościół katolicki w przestrzeni postsowieckiej). Szczegółowe informacje o podmiotach i wzajemnych relacjach pomiędzy nimi przedstawia rysunek 1 . 
Rysunek 1. Schemat relacji pomiędzy zagraniczną ojczyzną i zagranicznymi rodakami

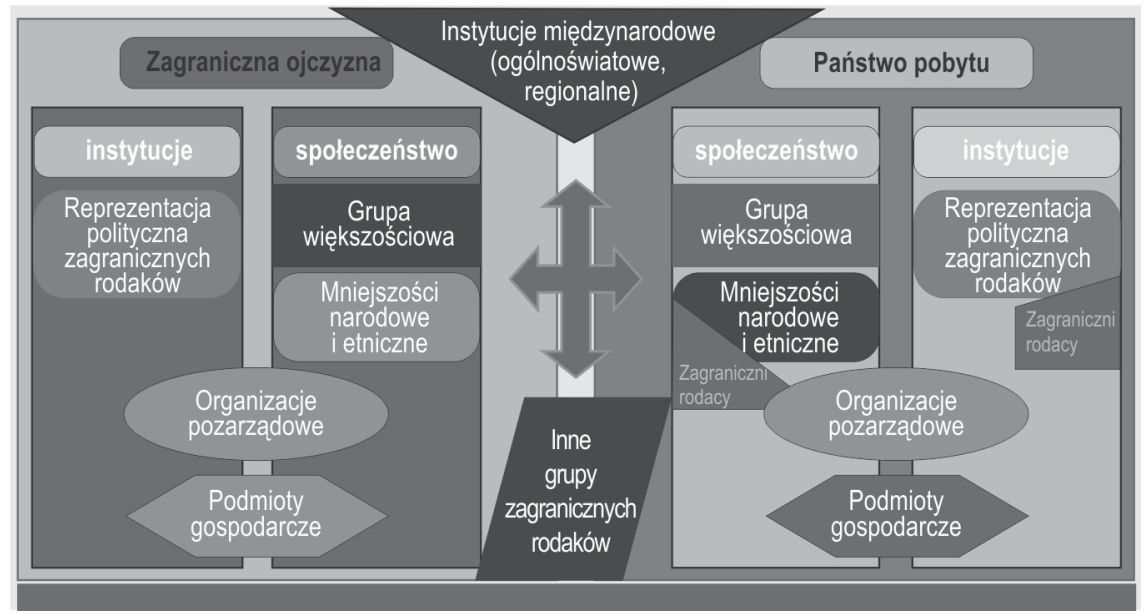

Źródło: opracowanie własne.

W proponowanym schemacie relacji należy uwzględnić też możliwość zróżnicowanych relacji pomiędzy zagraniczną ojczyzną i zagranicznymi rodakami w zależności od ich kraju pobytu. Oceniając więzi w tym typie wzajemnych stosunków można wyodrębnić trzy modele.

„Model aktywnego wsparcia” opisuje sytuację, w której zagraniczna ojczyzna posługując się szerokim spektrum instrumentów: prawnych, ekonomicznych czy politycznych realizuje szereg zadań mających na celu podtrzymanie odrębności i świadomości etnicznej wśród zagranicznych rodaków. Emigrację z pogranicza uznaje się za czynnik osłabiający potencjał ludnościowy grupy mniejszościowej i jako taka jest ona odbierana negatywnie. Dofinansowywanie rozmaitych przedsięwzięć (od edukacji po infrastrukturę lokalną) ma służyć wyrównaniu szans pomiędzy przedstawicielami grupy dominującej i zagranicznych rodaków, co w efekcie ma spowodować zachowanie istniejącego stanu demograficznego. Nowoczesnym instrumentem potęgującym więź wspólnotową z zagranicznymi rodakami jest wydawanie formalnego potwierdzenia zaistnienia takiej relacji $\mathrm{w}$ postaci dokumentu, który jednocześnie nie poświadcza obywatelstwa - tzw. przywilej ojczyźniany (tak zwane karty narodowe). W niektórych państwach rezygnuje się też z umożliwiania edukacji na poziomie wyższym w zagranicznej ojczyźnie, uznając, że w większości przypadków prowadzi to do nieintencjonalnego osłabienia środowisk zagranicznych rodaków poprzez drenaż i repatriację/ekspatriację najbardziej aktywnych osób. Aby 
przeciwdziałać takim procesom jest tworzona oferta stypendialna dla osób podejmujących studia w państwie obywatelstwa, a w rzadkich przypadkach tworzone są uczelnie za granicą (lub filie krajowych uczelni) mające na celu zaspokojenie potrzeb grupy mniejszościowej.

"Model koncentracyjno-państwowy” zakłada, że podtrzymywanie więzi z zagranicznymi rodakami będzie wywoływało napięcia w stosunkach międzypaństwowych, a zatem celowe wydaje się usunięcie przeszkody w ułożeniu poprawnych relacji w postaci likwidacji skupisk mniejszości narodowej. Wprawdzie tego rodzaju działania muszą w pewnym momencie doprowadzić do likwidacji pogranicza lub jego znaczącego ograniczenia terytorialnego, ale $\mathrm{z}$ drugiej strony przynoszą korzyść w postaci znaczącego wzmocnienia potencjału demograficznego w zagranicznej ojczyźnie, i o ile jest taka potrzeba, wykorzystania go na potrzeby wewnętrznego rynku pracy. Najskuteczniejszym instrumentem w tym zakresie jest prowadzenie aktywnej polityki repatriacyjnej/ekspatriacyjnej (w zależności od przyjętego kryterium: terytorium państwa czy historyczny obszar zasiedlenia).

„Model neutralny” oznacza dystansowanie się przedstawicieli władz i środowisk zagranicznej ojczyzny od postulatów i potrzeb grup zagranicznych rodaków. Z perspektywy zagranicznej ojczyzny przyjmuje się założenie, że wszelkie potrzeby obywateli innego państwa - także tych należących do grupy mniejszościowej, powinny być zaspokajane przez instytucje i siły społeczne w państwie obywatelstwa. W modelu tym kryterium obywatelstwa i respektowanie nadrzędności relacji państwo-obywatel ma wymiar decydujący, nawet jeśli w oczywisty sposób w państwie obywatelstwa prowadzone są działania naruszające prawa mniejszości narodowej.

Z perspektywy zagranicznej ojczyzny istnieje możliwość zastosowania „podejścia mieszanego", uwzględniającego rozmaite działania występujące w poszczególnych modelach. Oznacza to istnienie w porządku prawnym danego kraju instrumentów pozwalających na udzielaniu pomocy zagranicznym rodakom $\mathrm{w}$ ich państwie obywatelstwa, jak również przesiedlanie się do zagranicznej ojczyzny.

Należy podkreślić, że niezależnie od wybranego modelu zakres możliwych interwencji mający na celu zaspokojenie potrzeb zagranicznych rodaków dotyczy między innymi działań z tak zróżnicowanych obszarów jak: polityka imigracyjna (repatriacja/ekspatriacja, polityka wizowa i pobytowa), polityka rynku pracy, polityka edukacyjna, polityka informacyjna, polityka historyczna, polityka zdrowotna. 


\section{Cele utrzymywania związków pomiędzy zagranicznymi rodakami i zagranicznymi ojczyznami}

Duże znaczenie posiada określenie intencji stron prowadzących działania na rzecz rodaków za granicą. Analiza polityk poszczególnych państw środkowoeuropejskich pozwala na stwierdzenie, że zasadniczo wyodrębnia się trzy takie cele:

- kulturowy,

- polityczny,

- ekonomiczny.

Działania mające na celu utrzymanie, ugruntowanie lub rozprzestrzenienie dorobku kulturowego wybranej grupy etnicznej - w tym także przedsięwzięcia z zakresu szkolnictwa, powinny być oceniane jako oddziaływanie na środowisko, w którym żyją zagraniczni rodacy, a tym samym jako wzmocnienie ich pozycji w państwie obywatelstwa. Obecność, popularność i dowartościowanie kultury innego narodu, szczególnie na pograniczu, ma istotne skutki. Jeszcze wyraźniejsze następstwa przynoszą takie działania, jeśli ma miejsce współpraca polityczna i gospodarcza pomiędzy zagraniczną ojczyzną i państwem obywatelstwa.

Realizacja celów politycznych poprzez współpracę z zagranicznymi rodakami ma dwojaki wymiar. Po pierwsze, pozwala na wprowadzenie do dyskursu publicznego problematyki zagranicznych rodaków i konsolidowanie środowisk zainteresowanych zagadnieniami związanymi z sytuacją za granicą, co może przynosić profity polityczne. Po drugie, posiadająca oparcie za granicą mniejszość zyskuje istotną pozycję polityczną w kraju obywatelstwa, mając możliwości oddziaływania na proces decyzyjny.

Więź z zagranicznymi rodakami ma także wymiar ekonomiczny. Przy czym, zagadnienia obejmujące problematykę demograficzną i sprawy rynku pracy w zagranicznej ojczyźnie wydają się najistotniejsze. Przede wszystkim w zależności od ustalonych założeń polityki imigracyjnej można kompensować deficyty w strukturze demograficznej państwa i/lub oddziaływać na strumienie napływu pracowników (stałych lub sezonowych). Zagraniczni rodacy są szczególną grupą, która nie wymaga realizacji kosztownych programów adaptacyjnych, nie musi przełamywać bariery językowej i jest akceptowana w społeczeństwie zagranicznej ojczyzny. Z perspektywy ekonomicznej zagraniczni rodacy mogą też odegrać rolę w przypadku, gdy zamieszkiwany przez nich obszar ma znaczenie gospodarcze i znajduje się na nim infrastruktura przemysłowa. Wówczas - stosując rozmaite instrumenty polityczne (na przykład postulaty związków zawodowych, postulaty 
środowisk troszczących się o przyrodę) zagraniczni rodacy mogą pośrednio wypływać na sprawy gospodarcze kraju obywatelstwa.

\section{Pogranicza w Europie Środkowo-Wschodniej po przełomie lat $1989 / 1990$}

Polityczne, gospodarcze i społeczne zmiany, które nastąpiły w latach 1989/1990 były skutkiem procesów mających swój początek już wcześniej. Przede wszystkim podkreślenia wymaga fakt wytworzenia się nowych granic państwowych po zakończeniu II wojny światowej i towarzyszących im masowym ruchom ludności (wewnętrznym i zewnętrznym). W miejsce historycznego przemieszania grup etnicznych powstawały nowe, o innej jakościowo specyfice (na przykład Warmia i Mazury). Ponadto, dominujący w regionie system polityczny uniemożliwiał i hamował inicjatywy mające na celu utrzymanie odrębnej tożsamości, w tym także służące temu celowi kontakty transgraniczne.

Natomiast już od lat osiemdziesiątych na sytuację obszarów pogranicza w Europie Środkowo-Wschodniej silnie oddziaływały między innymi zmiany struktury demograficznej w poszczególnych państwach, niska rentowność produkcji przemysłowej, wysokie aspiracje materialne ludności. W tym okresie w Związku Sowieckim (republiki bałtyckie, republiki kaukaskie) i Jugosławii (Chorwacja, Słowenia) coraz bardziej istotne stawały się opinie płynące ze środowisk aspirujących do niepodległości państwowej lub znacznej autonomii. Naturalną konsekwencją tych dążeń stawała się kwestia ustalenia przebiegu granic. Dekadę później wieloetniczne państwa: Jugosławia (w zmienionym kształcie istniała od 1991 do 2003 roku), Czechosłowacja i Związek Sowiecki przestały w ogóle istnieć. Dotychczasowe pogranicza zmieniły swoją specyfikę na skutek masowej emigracji lub czystek etnicznych (szczególnie w byłej Jugosławii). Warto też podkreślić, że na obszarze wspomnianych trzech państw powstały nowe granice - czasem szczelnie dzielące mniejszość narodową (na przykład obszary zwartego osiedlenia Polaków wzdłuż granicy Litwy i Białorusi).

W omawianym okresie nastąpiły też bardzo głębokie zmiany w strukturze własności podmiotów gospodarczych i nieruchomości, których beneficjentami stali się przedstawiciele dominujących grup etnicznych w poszczególnych państwach. Niezwykle wymownym i z trudem przenikającym do dyskursu publicznego przykładem tego procesu jest „zwrot” gruntów w regionie wileńskim - podczas którego przy zastosowaniu rozmaitych instrumentów prawnych i finansowych pozbawiono prawa do od- 
zyskania własności większość spadkobierców narodowości polskiej [Kurcz 2005: 188; Żołędowski 2003: 225 i nast.]. Działanie to faktycznie stanowiło zwieńczenie rozpoczętego jeszcze w 1939 roku procesu depolonizacji Wilna i jego okolic. Na podobnych zasadach przebiegał proces reprywatyzacji w innych państwach regionu (na przykład Rumunia, była Czechosłowacja, Jugosławia, Bułgaria). W oczywisty sposób potencjał ekonomiczny (lub jego brak) wyznaczał w późniejszym okresie możliwości (lub ich brak) zaspokojenia potrzeb poszczególnych grup zagranicznych rodaków. Zapewne wytworzenie się trwałego ekonomicznego upośledzenia grup mniejszości etnicznych spowodowało poszukiwanie nowych instrumentów prawnych i wprowadzenie dokumentów, które nie potwierdzają obywatelstwa, ale jednocześnie stwierdzają związek z zagraniczną ojczyzną [Hut 2014: 215 i nast].

Podkreślenia wymagają też zmiany na pograniczach w Europie Środkowej i Wschodniej, będące skutkiem procesów migracyjnych po otwarciu rynków pracy w UE dla obywateli „nowych” państw członkowskich. Ludność z obszarów pogranicznych w znacznej skali wyemigrowała, ale też jednocześnie „przeniosła” pogranicze do nowych miejsc pobytu - w Wielkiej Brytanii, państwach skandynawskich czy w Niemczech.

Wraz z powstaniem nowych państw w Europie Środkowej i Wschodniej podjęto działania na rzecz ułożenia na nowo wzajemnych stosunków międzypaństwowych, a w tym także uregulowania statusu zagranicznych rodaków w ościennych państwach. Podkreślenia wymaga obfitość interpretacyjna w tym zakresie. Warto zaznaczyć, że w podpisywanych przez przedstawicieli najwyższych władz RP traktatach dobrosąsiedzkich znajdują się odniesienia do poszczególnych mniejszości narodowych (na przykład Białorusinów, Ukraińców), ale także do niezwykle obszernej grupy „obywateli Rzeczypospolitej Polskiej wywodzących się z Rosji” [Traktat między Rzecząpospolitą Polską a Federacją Rosyjską o przyjaznej i dobrosąsiedzkiej współpracy, Dz. U. 1993 r., nr 61, poz. 291; Traktat między Rzecząpospolitą Polską a Republiką Białoruś o dobrym sąsiedztwie i przyjaznej współpracy, Dz. U. 1993 r., nr 118, poz. 527; Traktat między Rzecząpospolitą Polską a Ukrainą o dobrym sąsiedztwie, przyjaznych stosunkach i współpracy, Dz. U. 1993 r., nr 125, poz. 573; Traktat między Rzecząpospolitą Polską a Republiką Litewską o przyjaznych stosunkach i dobrosąsiedzkiej współpracy, Dz. U. 1995 r., nr 15, poz. 71].

Efektem przyjętych rozwiązań prawnych - poza pozostawiającym nieograniczone pole do interpretacji wytworzeniem się grupy osób „wywodzących się z Rosji” - stało się swoiste zalegalizowanie współpracy zagranicz- 
nych ojczyzn z zagranicznymi rodakami. Władze poszczególnych państw w regionie zyskały potwierdzone przez władze sąsiednich państw uprawnienia do udzielania wsparcia i pomocy osobom poczuwającym się do związku z innym państwem niż kraj obywatelstwa.

Na gruncie regulacji międzynarodowych także nastąpiła zmiana, której symbolem jest Konwencja ramowa o ochronie mniejszości narodowych (Framework Convention for the Protection of National Minorities). Wprawdzie nie zawiera ona definicji „mniejszości narodowej” - co otwiera szerokie możliwości interpretacyjne w zakresie protekcji poszczególnych grup, niemniej jednak ma ona międzynarodowy charakter i stanowi potwierdzenie prawa do ochrony (zarówno ze strony państwa obywatelstwa, jak też zagranicznej ojczyzny). Kwestią dyskusyjną jest przestrzeganie zapisów Konwencji przez władze poszczególnych państw-stron, ale podobne kontrowersje wywołuje sprawa dochowania ustaleń z zawartych traktatów dobrosąsiedzkich.

\section{Podsumowanie}

Współczesne gwarancje przestrzegania praw mniejszości i prawo do zaspokajania ich potrzeb przez zagraniczne ojczyzny zmieniły swój wymiar. Omawiane ustalenia międzypaństwowe - wzbogacone szeregiem umów bilateralnych, obejmujących na przykład sferę edukacji czy migracji transgranicznych, zostały przyjęte w szczególnym momencie wielkich zmian politycznych i społecznych w Europie Środkowej i Wschodniej. Jednocześnie wynikały one z tradycyjnego pojmowania sytuacji zagranicznych rodaków - pozostających poza oddziaływaniem procesów następujących w ich zagranicznych ojczyznach, a przede wszystkim przy przyjęciu założenia, że są oni grupą systemowo upośledzoną. Przeniesienie idei zjednoczonej Europy na obszar dawnych państw bloku wschodniego i postęp technologiczny (a dzięki niemu otwartość przepływu informacji) skutecznie uniemożliwiły tradycyjne odseparowywanie zagranicznych rodaków od związków z ich zagranicznymi ojczyznami. Kontakty stały się częstsze, niewymuszone okolicznościowymi wizytami na wysokim szczeblu i przede wszystkim objęły szersze grupy osób.

W nadchodzącej dekadzie należy spodziewać się pogłębienia zmiany jakościowej obszarów pogranicza i jego dalszego „otwarcia”. Bez wątpienia na taką sytuację będą wpływały prace w poszczególnych państwach nad przekształceniem i rozszerzeniem istniejących instrumentów prawnych o charakterze jednostronnym (nie negocjowane z krajem obywatelstwa zagranicznych rodaków), rozumianych jako element polityki demograficznej, 
polityki rynku pracy i polityki gospodarczej. Natomiast ich efektywność stanie się prostą konsekwencją polityk realizowanych wkrajach obywatelstwa wobec zagranicznych rodaków. Można przypuszczać, że na pograniczach będą narastały zróżnicowania - nowe nierówności społeczno-ekonomiczne, według kryterium etnicznego, to zaś będzie skutkowało pojawianiem się napięć, których rozładowanie będzie możliwe wyłącznie przy zaistnieniu współpracy pomiędzy władzami zagranicznych ojczyzn, władzami państw obywatelstwa i przede wszystkim zagranicznych rodaków.

\section{Bibliografia}

Brubaker R. (1998), Nacjonalizm inaczej. Struktura narodowa i kwestie narodowe w nowej Europie, przeł. J. Łuczyński, Warszawa - Kraków.

Hut P. (2014), Polska wobec Polaków w przestrzeni poradzieckiej. Od solidaryzmu etnicznego do obowiazku administracyjnego, Warszawa.

Klatta P. (2003), Granica, pogranicze i przygranicze, transgraniczność $i$ wspólpraca transgraniczna, [w:] E. Skorupska-Raczyńska (red.), Dziedzictwo kulturowe regionu gorzowskiego, Gorzów Wlkp.

Kurcz Z. (2005), Mniejszość polska na Wileńszczyźnie. Studium socjologiczne, Wrocław.

Niemyska M. (1936), Wychodźcy po powrocie do kraju. Remigranci w województwie białostockiem w świetle ankiety 1934 roku, wstępem opatrzył L. Krzywicki, Warszawa.

Niemyska-Hessen M. (1939), Remigracja $z$ Francji w dobie kryzysu na tle wyników ankiety 1936 roku, Warszawa.

Ossowski S. (1967), Zagadnienia więzi regionalnej i więzi narodowej na Śląsku Opolskim, [w:] Dzieła, t. 3, Warszawa.

Stola D. (2010), Kraj bez wyjścia? Migracje z Polski 1949-1989, Warszawa.

Traktat między Rzecząpospolitą Polską a Federacją Rosyjską o przyjaznej i dobrosąsiedzkiej współpracy, Dz. U. 1993 r., nr 61, poz. 291.

Traktat między Rzecząpospolitą Polską a Republiką Białoruś o dobrym sąsiedztwie i przyjaznej współpracy, Dz. U. 1993 r., nr 118, poz. 527.

Traktat między Rzecząpospolitą Polską a Ukrainą o dobrym sąsiedztwie, przyjaznych stosunkach i współpracy, Dz. U. 1993 r., nr 125, poz. 573.

Traktat między Rzecząpospolitą Polską a Republiką Litewską o przyjaznych stosunkach i dobrosąsiedzkiej współpracy, Dz. U. 1995 r., nr 15, poz. 71.

Żołędowski C. (2003), Białorusini i Litwini w Polsce, Polacy na Białorusi i Litwie. Uwarunkowania wspótczesnych stosunków między większościa i mniejszościami narodowymi, Warszawa. 


\section{SUMMARY}

\section{Foreign compatriots and borderland in Central and Eastern Europe after the 1989/1990 year}

This article describes situation of foreign compatriots on the borderland after great changes in 1989/1990 year. The autor focuses considerations on social, economic and political conditions of relations between dominant majority and minority (foreign compatriots) and national homeland. After necessary clarification of definitions takes to description of the overall circumstances on the borderland.

Later in the article are graphic presentation and model types of relations between different political, social and economic subjects. At the end the is prediction of changes on the borderlands in future.

KEYWORDS: foreign compatriot, national homeland, Central and Eastern Europe 